International Journal of

Environmental Research and

Public Health

ISSN 1660-4601

www.mdpi.com/journal/ijerph

Article

\title{
Biodegradation of di-n-Butyl Phthalate by Achromobacter sp. Isolated from Rural Domestic Wastewater
}

\author{
Decai Jin ${ }^{1, \dagger}$, Xiao Kong ${ }^{1, \dagger}$, Yujie Li ${ }^{2, \dagger}$, Zhihui Bai ${ }^{1, *}$, Guoqiang Zhuang ${ }^{1}$, Xuliang Zhuang ${ }^{1}$ and \\ Ye Deng ${ }^{1, *}$
}

1 Key Laboratory of Environmental Biotechnology, Research Centre for Eco-Environmental Sciences, Chinese Academy of Sciences, Beijing 100085, China; E-Mails: dcjin@rcees.ac.cn (D.J.); kongxiaozaikeda@163.com (X.K.); gqzhuang@rcees.ac.cn (G.Z.); xlzhuang@rcees.ac.cn (X.Z.)

2 Environmental Protection Bureau of Shijiazhuang City, Shijiazhuang 050021, China;

E-Mail: 1yj8026@163.com

$\dagger$ These authors contributed equally to this work.

* Authors to whom correspondence should be addressed; E-Mails: zhbai@rcees.ac.cn (Z.B.); yedeng@rcees.ac.cn (Y.D.); Tel.: +86-10-6284-9156 (Z.B.); Fax: +86-10-6292-3563 (Z.B.).

Academic Editor: Miklas Scholz

Received: 17 August 2015 / Accepted: 16 October 2015 / Published: 26 October 2015

\begin{abstract}
A bacterial strain W-1, isolated from rural domestic wastewater, can utilize the environmental hormone di-n-butyl phthalate (DBP) as the sole carbon and energy source. The isolated bacterium species was confirmed to belong to the genus Achromobacter based on its $16 \mathrm{~S}$ rRNA gene sequence. The results of substrate utilization tests showed that the strain W-1 could utilize other common phthalates and phenol. High-performance liquid chromatography analysis revealed that the optimal conditions for DBP degradation were $\mathrm{pH}$ $7.0,35^{\circ} \mathrm{C}$, and an agitation rate of $175 \mathrm{rpm}$. Under these conditions, $500 \mathrm{mg} / \mathrm{L}$ of DBP was completely degraded within $30 \mathrm{~h}$. The effects of heavy metals $\left(50 \mathrm{mg} / \mathrm{L} \mathrm{Cu}^{2+}\right.$ and $500 \mathrm{mg} / \mathrm{L}$ $\mathrm{Pb}^{2+}$ ) and surfactants (100 mg/L SDS and $500 \mathrm{mg} / \mathrm{L}$ Tween 20) on DBP degradation were investigated. The results demonstrated that $\mathrm{Cu}^{2+}$ and SDS severely inhibited DBP degradation and $\mathrm{Pb}^{2+}$ weakly inhibited DBP degradation, while Tween 20 greatly enhanced DBP degradation. Furthermore, phthalate degradation genes were found to be located on a plasmid present in Achromobacter sp. W-1.
\end{abstract}


Keywords: biodegradation; di- $n$-butyl phthalate; environmental hormone; Achromobacter; heavy metals; surfactants

\section{Introduction}

Phthalic acid esters (PAEs) are among the most widely used synthetic chemicals and are employed as additives to improve the flexibility, transparency, durability, and longevity of plastics. PAEs have been detected in soils, water, and air and have become a major environmental concern. Currently, PAEs are listed as primary controlled pollutants by the Environmental Monitoring Center of China and the United States Environmental Protection Agency because of their carcinogenicity and mutagenicity and their ability to act as environmental hormones [1]. As one of the most extensively used PAEs, di- $n$-butyl phthalate (DBP) has become a ubiquitous contaminant in the environment [2]. For example, DBP has been detected in the water and sediment samples with concentration ranges of $1.0-13.5 \mu \mathrm{g} / \mathrm{L}$ and $0.3-30.3 \mu \mathrm{g} / \mathrm{g}$, respectively [3]. Wang et al. [4] reported a total of six priority control phthalates ranging from 0.51 to $7.16 \mathrm{mg} / \mathrm{kg}$ in vegetables and 0.40 to $6.20 \mathrm{mg} / \mathrm{kg}$ in soils, with average concentrations of 2.56 and $2.23 \mathrm{mg} / \mathrm{kg}$, respectively. DBP, di-(2-ethylhexyl) phthalate (DEHP), and di- $n$-octyl phthalate (DOP) contributed more than $90 \%$ to these levels. DBP in the environment can be taken up by plants and other living organisms, thereby entering the food supply. Numerous studies have shown that DBP has anti-androgenic and estrogenic effects in male rats and fish [5], and has also been related to reproductive defects in humans [6]. Since the hydrolysis and photolysis of phthalate esters are very slow, microbial degradation is the main approach used to completely mineralize phthalate esters in the natural environment [7]. Thus, it is critical to isolate microbial strains that efficiently biodegrade DBP in various environments.

Over the past few decades, several phthalate esters-degrading bacterial strains exhibiting diverse geographical distributions have been isolated, including Rhodococcus sp. [8], Agrobacterium sp. [9], Gordonia sp. [10], Enterobacter sp. [11], Pseudomonas sp. [12], Burkholderia sp. [13], Bacillus sp. [14], and Deinococcus radiodurans and Pseudomonas stutzeri [15]. Moreover, considerable research efforts have been devoted to determining the metabolic pathways and mechanisms of PAE biodegradation. In general, the process of PAE biodegradation is as follows: initially, bacteria hydrolyze PAEs into phthalate and the corresponding alcohols, and then phthalate is metabolized to protocatechuate by either phthalate 4, 5-dioxygenase in Gram-negative bacteria or phthalate 3, 4-dioxygenase in Gram-positive bacteria. Finally, protocatechuate is further metabolized into $\mathrm{CO}_{2}$ and $\mathrm{H}_{2} \mathrm{O}$ through a series of reactions [16,17]. To date, several genes encoding phthalate-degrading enzymes (esterase, phthalate hydrolase, and phthalate catabolic gene cluster, etc.) have been cloned and characterized [17-21]. However, very little information is available regarding the mechanism by which bacterial strains degrade PAEs in rural domestic wastewater. A deeper understanding of this topic could provide a basis for enhancing PAE removal in wastewater treatment plants in rural areas.

In this study, we isolated a bacterial strain W-1 from rural domestic wastewater, which was further identified as a species of the genus Achromobacter. We examined the effects of environmental factors on the DBP degradation ability of $\mathrm{W}-1$, analyzed how heavy metals and surfactants affect DBP 
biodegradation, and investigated the degradation kinetics of DBP at distinct substrate concentrations. Furthermore, we conducted plasmid-elimination experiments in order to determine whether the DBP-degradation genes were located in the plasmid present in $\mathrm{W}-1$.

\section{Experimental Section}

\subsection{Chemicals}

DBP, dimethyl phthalate (DMP), diethyl phthalate (DEP), DOP, DEHP, and phenol at greater than 98\% purity were purchased from Alfa Aesar (Ward Hill, MA, USA). Methanol, ethyl acetate, and hexane (high-performance liquid chromatography grade) were purchased from Fisher Scientific (Waltham, MA, USA). All other chemicals and solvents were of analytical reagent grade.

\subsection{Isolation and Identification of Bacteria}

The bacterium was isolated from wastewater obtained from a rural sewage treatment plant in the Huairou District of Beijing (40.3N', 116.6E'). One milliliter of wastewater was added to $100 \mathrm{~mL}$ of mineral salt medium (MSM, g/L: $5.8 \mathrm{~K}_{2} \mathrm{HPO}_{4}, 4.5 \mathrm{KH}_{2} \mathrm{PO}_{4}, 2.0\left(\mathrm{NH}_{4}\right)_{2} \mathrm{SO}_{4}, 0.16 \mathrm{MgCl}_{2}, 0.02 \mathrm{CaCl}_{2}$, $0.0024 \mathrm{Na}_{2} \mathrm{MoO}_{4} \cdot 2 \mathrm{H}_{2} \mathrm{O}, 0.0018 \mathrm{FeCl}_{3}$, and $\left.0.0015 \mathrm{MnCl}_{2} \cdot 2 \mathrm{H}_{2} \mathrm{O}\right)$. The $\mathrm{pH}$ of the medium was adjusted to 7.0 , and then the medium containing $100 \mathrm{mg} / \mathrm{L}$ of PAEs $(25 \mathrm{mg} / \mathrm{L}$ each of DMP, DEP, DBP, and DEHP) was autoclaved at $115^{\circ} \mathrm{C}$ for $30 \mathrm{~min}$. The culture suspension was incubated for $1-2$ weeks at $30^{\circ} \mathrm{C}$ on a rotary shaker at $175 \mathrm{rpm}$. Next, $1 \mathrm{~mL}$ of the enriched culture solution was transferred into fresh medium containing a higher concentration of PAEs. The final enriched solution was streaked onto MSM agar (18 g/L) plates supplemented with a mixture of PAEs $(500 \mathrm{mg} / \mathrm{L})$. Visible colonies appeared after incubation for 1 week. The colonies were then transferred to fresh plates and the incubation process was repeated until pure cultures were obtained. The pure cultures were phylogenetically analyzed by sequencing their $16 \mathrm{~S}$ rRNA genes, which were PCR-amplified using the universal primers $27 \mathrm{~F}$ and 1492R. The PCR thermal cycling consisted of an initial denaturation at $95^{\circ} \mathrm{C}$ for $10 \mathrm{~min}$, followed by 35 cycles of $94{ }^{\circ} \mathrm{C}$ for $45 \mathrm{~s}, 55^{\circ} \mathrm{C}$ for $45 \mathrm{~s}$, and $72{ }^{\circ} \mathrm{C}$ for $90 \mathrm{~s}$, plus a final step at $72{ }^{\circ} \mathrm{C}$ for $10 \mathrm{~min}$. PCR products were cloned and sequenced. The obtained sequences were subjected to BLAST homology searching (http://www.ncbi.nlm.nih.gov/BLAST). Based on the sequencing results, the 16S rRNA gene sequences of higher similarity-related strains from GenBank database were selected. Multiple sequence alignment was performed and a phylogenetic tree was generated using MEGA4.0 software.

\subsection{Substrate Utilization Tests}

To examine the ability of strain W-1 to utilize different substrates, W-1 was cultured in liquid MSM supplemented with $500 \mathrm{mg} / \mathrm{L}$ of one of the following substrates: DMP, DEP, DBP, DOP, DEHP, and phenol as the sole source of carbon and energy. The suspension was incubated at $30{ }^{\circ} \mathrm{C}$ on a rotary shaker at $175 \mathrm{rpm}$. After 3 days of incubation, the biomass concentration was determined by optical density measurements at $600 \mathrm{~nm}$. 


\subsection{Effects of pH, Temperature, and Agitation Rate on DBP Biodegradation}

Strain W-1 was cultivated in MSM at $30^{\circ} \mathrm{C}$ on a rotary shaker at $175 \mathrm{rpm}$, harvested after $48 \mathrm{~h}$, washed three times with $0.02 \mathrm{M}$ potassium phosphate buffer $(\mathrm{pH}$ 7.2) under sterile conditions, and resuspended in the same phosphate buffer to an $\mathrm{OD}_{600}$ of 0.2 . A stock solution of $10 \mathrm{~g} / \mathrm{L} \mathrm{DBP}$ was prepared by dissolving DBP in $n$-hexane, and then equal amounts of the solutions were added to $50 \mathrm{~mL}$ sterilized Erlenmeyer flasks. The $n$-hexane was evaporated and then the samples were inoculated with $1 \mathrm{~mL}$ of the cell suspension prepared in $20 \mathrm{~mL}$ of MSM. To determine the optimal conditions for biodegradation, the degradation of $500 \mathrm{mg} / \mathrm{L}$ DBP by W-1 was examined at different $\mathrm{pH}(5.0,6.0,7.0$, 8.0, 9.0, 10.0, and 11.0), temperatures $\left(25,30,35,40\right.$, and $\left.45{ }^{\circ} \mathrm{C}\right)$, and agitation rates $(0,75,150,175$, and $200 \mathrm{rpm})$. After incubation for $30 \mathrm{~h}$, samples were collected and subjected to high-performance liquid chromatography (HPLC) analysis. All experiments were performed in triplicate.

\subsection{Effects of Heavy Metals and Surfactant on DBP Degradation by Strain W-1}

Because heavy metals and surfactants are present in soil and water, they may influence the degradation of organic matter by microorganisms. Therefore, we investigated the effects of heavy metals $\left(\mathrm{Cu}^{2+}\right.$ and $\left.\mathrm{Pb}^{2+}\right)$ and surfactants (SDS and Tween 20) on the degradation of DBP by W-1; the following concentrations were tested: $50 \mathrm{mg} / \mathrm{L} \mathrm{Cu} ; 500 \mathrm{mg} / \mathrm{L} \mathrm{Pb} ; 100 \mathrm{mg} / \mathrm{L} \mathrm{SDS}$; and $500 \mathrm{mg} / \mathrm{L}$ Tween 20. The experiment was conducted in 50-mL Erlenmeyer flasks containing $20 \mathrm{~mL}$ of MSM supplemented with $500 \mathrm{mg} / \mathrm{L}$ of DBP. The culture was incubated on a rotary shaker at $175 \mathrm{rpm}$ and $30{ }^{\circ} \mathrm{C}$, and samples were withdrawn once every $8 \mathrm{~h}$ until $48 \mathrm{~h}$. The DBP residue was detected using HPLC. All experiments were performed in triplicate.

\subsection{Kinetics of DBP Degradation by Strain $W-1$}

The degradation of DBP at various initial substrate concentrations $(100,200,300,400$, and $500 \mathrm{mg} / \mathrm{L})$ was examined under optimal conditions. Samples were collected once every $5 \mathrm{~h}$ for a period of $30 \mathrm{~h}$, and HPLC analysis was performed to detect the DBP residue. All experiments were performed in triplicate.

\subsection{Plasmid Eliminate Experiment}

Plasmids were eliminated as described previously [22]. Briefly, the bacterial strain was inoculated in $20 \mathrm{~mL}$ of LB medium without or with $0.01 \%$ SDS. Cells were cultivated at $35^{\circ} \mathrm{C}$ and $175 \mathrm{rpm}$ for $16 \mathrm{~h}$, and the cultivation was repeated 3 times under this condition. The diluted bacteria were coated on LB agar medium and grown at $35{ }^{\circ} \mathrm{C}$ for $24 \mathrm{~h}$. Single colonies were propagated and the plasmids were extracted; plasmid isolation was repeated twice. Plasmid-removed cells and normal cells were inoculated into $100 \mathrm{~mL}$ of MSM containing $500 \mathrm{mg} / \mathrm{L} \mathrm{DBP}$ and grown at $35^{\circ} \mathrm{C}$ and $175 \mathrm{rpm}$, and the growth of these bacterial cells and their DBP degradation were compared.

\subsection{Analysis of DBP Residue}

A total of $20 \mathrm{~mL}$ of ethyl acetate was added directly to the flask, which was shaken up and then left standing until stratification. The ethyl acetate phase without bacteria was evaporated to dryness and 
dissolved in $10 \mathrm{~mL}$ of methanol. The methanol solution was filtered through a $0.22-\mu \mathrm{m}$ membrane filter before injection into the HPLC system equipped with a UV230+ UV-Vis detector and a Hypersil BDS-C18 $(200 \mathrm{~mm} \times 4.6 \mathrm{~mm}, 5 \mu \mathrm{m})$ chromatography column. The chromatographic conditions for detecting DBP were mobile phase: 9:1 (v/v) methanol-water, flow rate of $1 \mathrm{~mL} / \mathrm{min}$, and UV wavelength of $228 \mathrm{~nm}$.

\section{Results and Discussion}

\subsection{Isolation and Identification of Bacteria}

A bacterial strain (designated as $\mathrm{W}-1$ ) that can use DBP was enriched and isolated from rural domestic wastewater obtained from a wastewater-treatment plant. The properties of the original water were as follows: $\mathrm{pH}=7.60$, temperature $=12.2{ }^{\circ} \mathrm{C}$, salinity $=566 \mathrm{mg} / \mathrm{L}, \mathrm{COD}=346 \mathrm{mg} / \mathrm{L}, \mathrm{SS}=26 \mathrm{mg} / \mathrm{L}$, anionic surfactant $=2.00 \mathrm{mg} / \mathrm{L}, \mathrm{TN}=54.6 \mathrm{mg} / \mathrm{L}, \mathrm{TP}=4.97 \mathrm{mg} / \mathrm{L}, \mathrm{Cl}^{-}=44.2 \mathrm{mg} / \mathrm{L}$, and total bacterial count $=(1.24 \pm 0.05) \times 10^{6} / \mathrm{mL}$. Strain W-1 was found to be a Gram-negative bacterium and its colonies were round, moist, neat, and smooth, ranging in color from white to light brown when grown on LB agar. The bacterium could utilize glucose, mannose, citrate, sorbitol, asparagine, and proline as sole carbon sources. Maltose, soluble starch, malonic acid, tryptophan, cysteine, and serine were not utilized. As shown in Figure 1, the size of strain W-1 was approximately $0.3-0.6 \mu \mathrm{m} \times 1.2-1.8 \mu \mathrm{m}$.

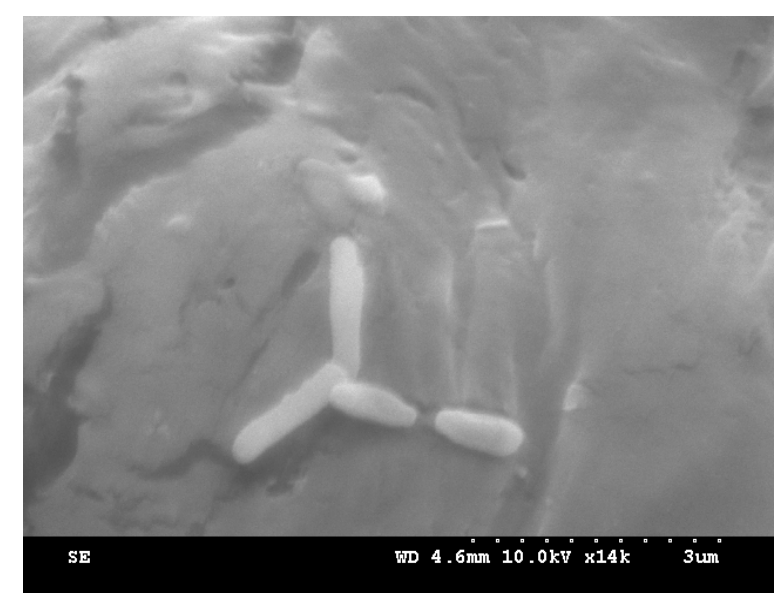

Figure 1. Scanning electron micrograph of strain W-1.

A BLAST analysis of the 16S rRNA gene sequence of W-1 (GenBank accession no. KP723191) revealed that this strain and several Achromobacter strains share an extremely high degree of homology $(>99 \%)$. Thus, strain W-1 was identified as belonging to the genus Achromobacter. The relationship between Achromobacter sp. strain W-1 and its close relatives based on 16S rRNA gene sequence analysis is shown in Figure 2. Although previous studies have shown that Achromobacter species can degrade $p$-nitrophenol [23], 2,4-dichlorophenol and phenol [24], acetochlor [25], and reduce high concentrations of $\mathrm{Cr}$ [26], only one recent study reported PAE degradation by pure cultures of Achromobacter [27]. 


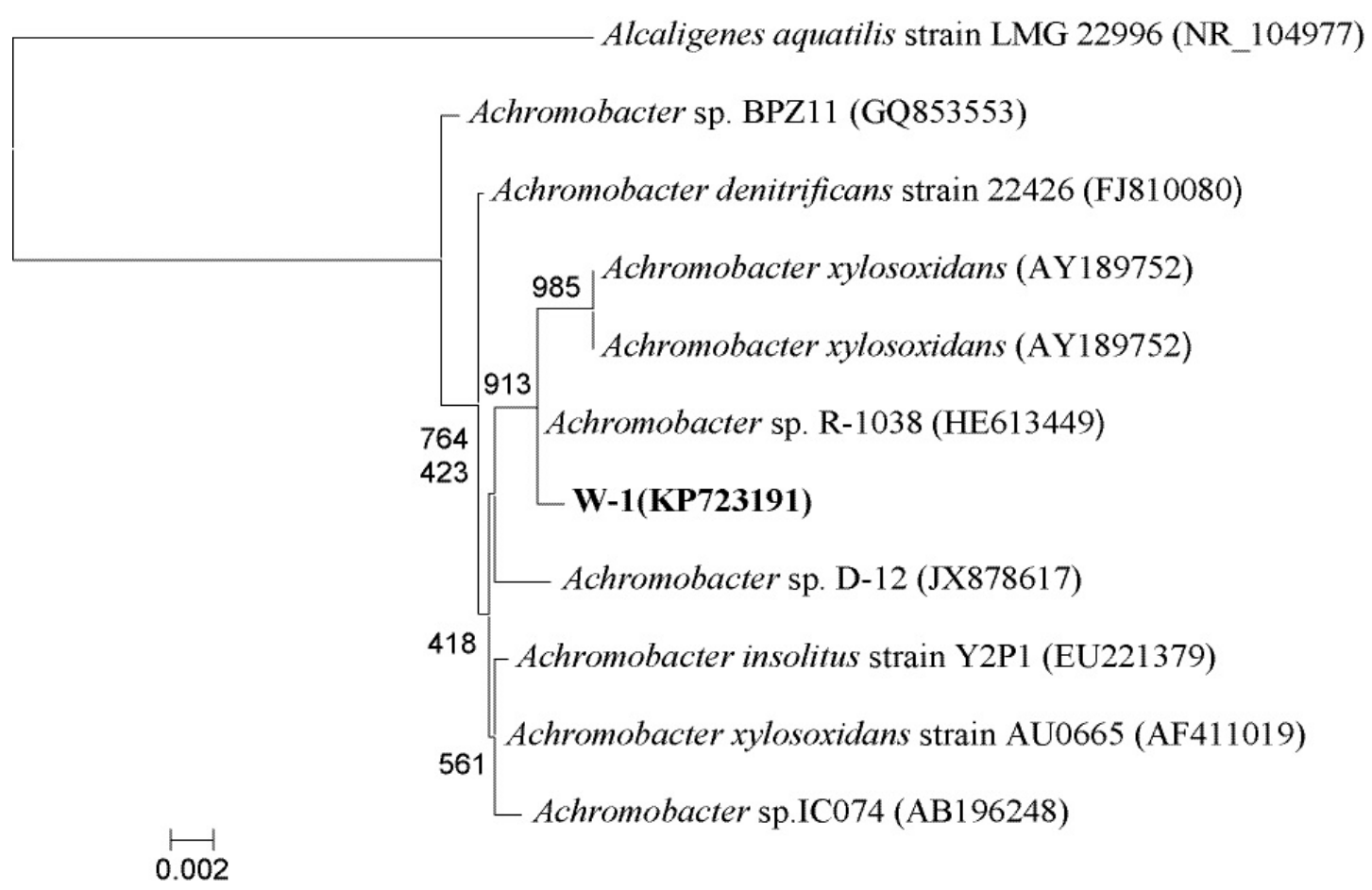

Figure 2. Phylogenetic tree derived from the $16 \mathrm{~S}$ rRNA gene sequence of strain W-1 and sequences of related species. Distances were calculated using the neighbor-joining method. Numbers at branch points are bootstrap values (based on 1000 samplings). Alcaligenes aquatilis strain LMG 22996T (NR_104977) was used as the out-group. Scale bars represent 0.002 substitutions per site.

\subsection{Substrate Utilization Tests}

Domestic wastewater typically contains diverse pollutants, and thus screening for strains that can degrade a broad spectrum of substrates is highly conducive for using these strains in practical engineering. The results of substrate utilization tests indicated that the isolate $\mathrm{W}-1$ degraded various phthalate esters (Table 1). The strain grew well in media containing DMP, DEP, DBP, DOP, and DEHP, demonstrating that $\mathrm{W}-1$ can utilize both short alkyl-chained PAEs and long alkyl-chained PAEs. Notably, strain W-1 can grow better in long alkyl-chained than in short alkyl-chained PAEs. Moreover, W-1 also used phenol, which is a widespread pollutant worldwide. Based on these results, DBP, which is one of most popular plasticizers, was used in further degradation tests [28].

Table 1. Substrate utilization profile of strain W-1.

\begin{tabular}{ccccccc}
\hline Substrate & DMP/OD $_{600}$ & DEP/OD $_{600}$ & DBP/OD $_{600}$ & DEHP/OD $_{600}$ & DOP/OD $_{600}$ & Phenol/OD $_{600}$ \\
\hline Utilization & $+/ 0.340$ & $+/ 0.426$ & $+/ 0.537$ & $+/ 1.179$ & $+/ 0.962$ & $+/ 0.902$ \\
\hline
\end{tabular}

Note: + , positive.

\subsection{Effects of $\mathrm{pH}$, Temperature, and Agitation rate on DBP Biodegradation}

The effects of $\mathrm{pH}$ on DBP degradation by strain $\mathrm{W}-1$ in the batch medium were tested at $30{ }^{\circ} \mathrm{C}$, and the results are shown in Figure 3. The DBP degradation rate increased rapidly when the $\mathrm{pH}$ was 
increased from 5.0 to 7.0. The highest DBP degradation rate (approximately 96.8\%) for strainW-1 was achieved at $\mathrm{pH}$ 7.0. However, the degradation rate decreased dramatically when $\mathrm{pH}$ exceeded 7.0. In the temperature effect test, the degradation rate increased when the temperature was increased from 25 to $35^{\circ} \mathrm{C}$, but the rate decreased at higher temperatures. Therefore, the optimal temperature for DBP degradation was $35{ }^{\circ} \mathrm{C}$. Finally, the DBP-degradation rate decreased when the agitation rate was increased from 0 to $175 \mathrm{rpm}$, but it decreased when the agitation rate was $>175 \mathrm{rpm}$. Collectively, these results revealed the optimal conditions for DBP degradation as $\mathrm{pH} 7.0,35^{\circ} \mathrm{C}$, and agitation rate of $175 \mathrm{rpm}$. No residual DBP was detected under this set of conditions within $30 \mathrm{~h}$. Pradeep et al. [27] reported that the optimal conditions for DEHP degradation by Achromobacter denitrificans strain SP1 were $32{ }^{\circ} \mathrm{C}$, agitation rate of $200 \mathrm{rpm}$, and $\mathrm{pH} 8.0$; thus, strain $\mathrm{W}-1$ and A. denitrificans strain SP1 exhibited similar trends with respect to optimal conditions.
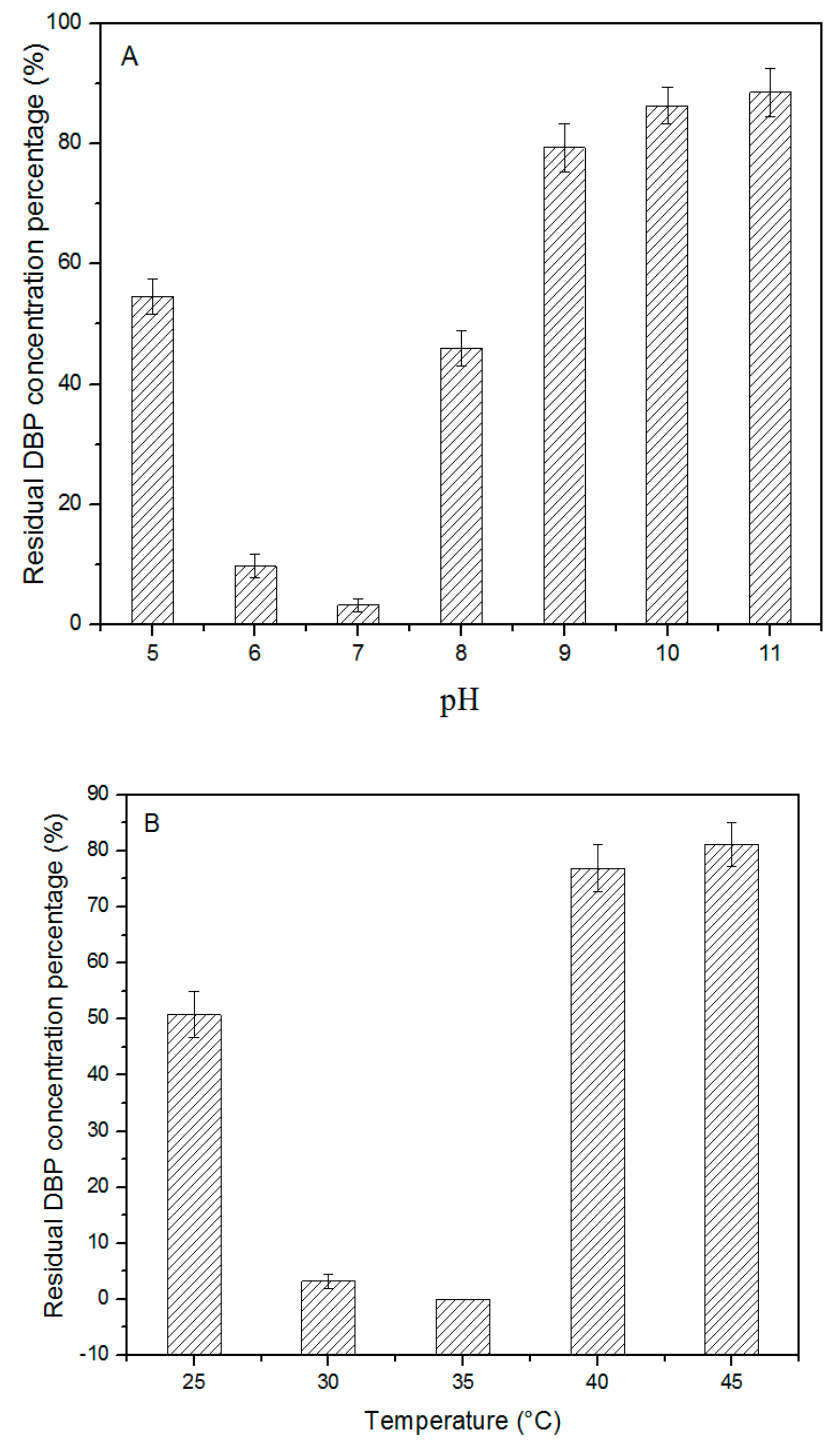

Figure 3. Cont. 


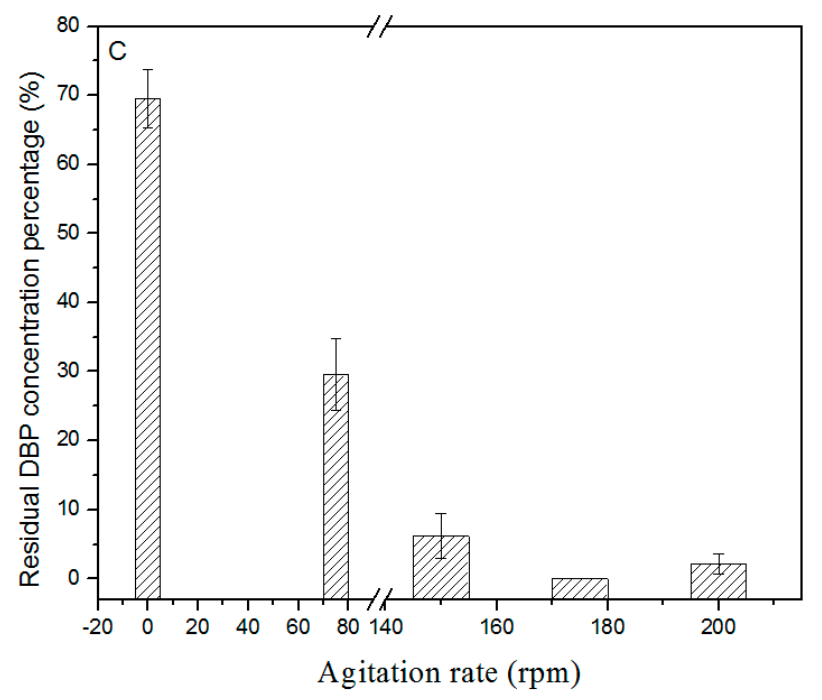

Figure 3. Effect of $\mathrm{pH}$, temperature, and agitation rate on degradation of DBP $(500 \mathrm{mg} / \mathrm{L})$ by strain $\mathrm{W}-1$. A: $\mathrm{pH}$; B: temperature; $\mathrm{C}$ : agitation rate; Error bars are the standard error of the mean (SEM) of DBP concentration from triplicate experiments.

\subsection{Effects of Heavy Metals and Surfactants on DBP Degradation by Strain W-1}

We examined how the degradation of DBP in culture medium was affected by the heavy metals $\mathrm{Cu}^{2+}$ $(50 \mathrm{mg} / \mathrm{L})$ and $\mathrm{Pb}^{2+}(500 \mathrm{mg} / \mathrm{L})$, and the surfactants SDS $(100 \mathrm{mg} / \mathrm{L})$ and Tween $20(500 \mathrm{mg} / \mathrm{L})$. The results presented in Figure 4 show that strain W-1 completely degraded DBP in the absence of $\mathrm{Cu}^{2+}$ or $\mathrm{Pb}^{2+}$ within $30 \mathrm{~h}$. However, W-1 was extremely sensitive to $\mathrm{Cu}^{2+}$ and SDS: almost no DBP degradation occurred in their presence. When $\mathrm{Pb}^{2+}$ was added to the reaction mixture, no marked effects on DBP degradation were observed; $98.2 \%$ of the DBP was degraded by $32 \mathrm{~h}$ and no DBP was detected at $40 \mathrm{~h}$. Finally, Tween 20 substantially enhanced DBP degradation: no DBP was detected by $24 \mathrm{~h}$ when this surfactant was present. These results indicate that various environmental factors must be considered when conducting bioremediation of sites contaminated with PAEs.

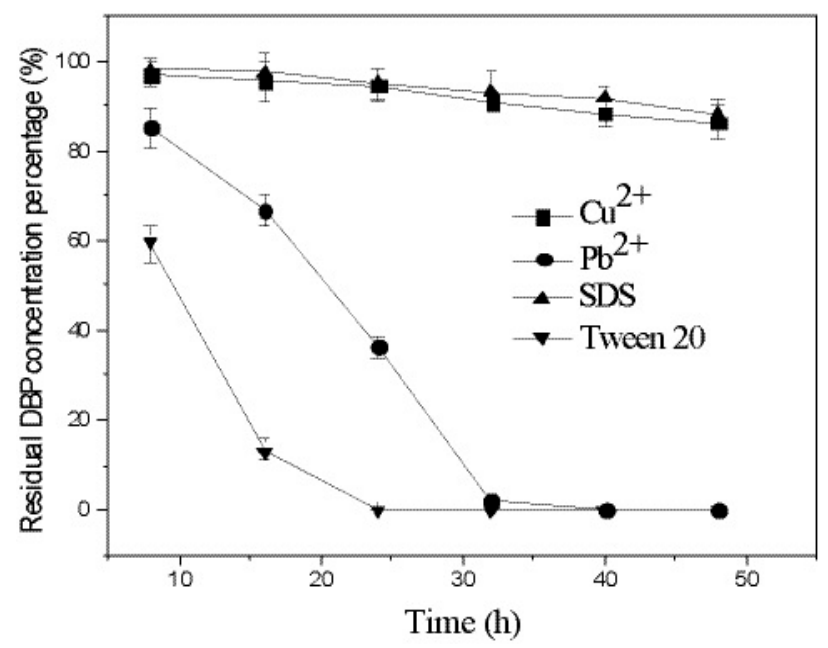

Figure 4. Effects of heavy metals and surfactants on the degradation of DBP. Error bars are the SEM of DBP concentration from triplicate experiments. 


\subsection{Kinetics of DBP Degradation by Strain $W-1$}

The degradation of DBP by strain W-1 at different initial concentrations was investigated. The results (Figure 5) show that strain W-1 completely degraded DBP within $20 \mathrm{~h}$ when the initial concentration was less than $200 \mathrm{mg} / \mathrm{L}$. When the initial concentration of DBP was between 300 and 500 $\mathrm{mg} / \mathrm{L}$, all DBP was degraded within $30 \mathrm{~h}$.

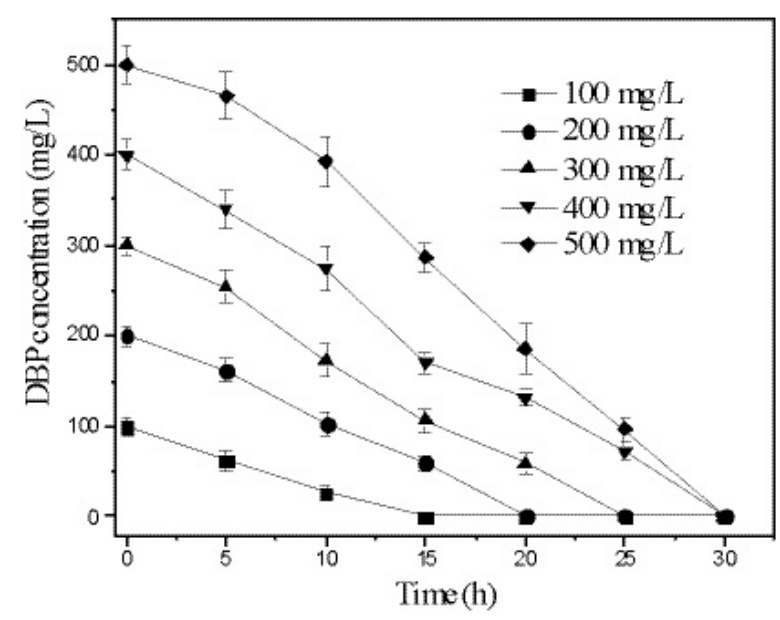

Figure 5. Degradation rate at different initial DBP concentrations. Error bars are the SEM of DBP concentration from triplicate experiments.

DBP biodegradation by strain $\mathrm{W}-1$ was assumed to fit the following first-order kinetic model: $\ln C=-k \mathrm{t}+\mathrm{b}(1)$, where $C$ is DBP concentration, $\mathrm{t}$ is time, $k$ is the first-order rate constant, and $\mathrm{b}$ is a constant. The half-life of DBP biodegradation by strain W-1 was calculated according to the following equation: $t_{1 / 2}=\ln \frac{2}{k}(2)$. The results in Table 2 show that the DBP-depletion curves were described accurately by the first-order kinetic equation, with high correlation coefficients $\left(\mathrm{R}^{2}>0.96\right)$ at initial DBP concentrations ranging from 100 to $400 \mathrm{mg} / \mathrm{L}$. To date, the first-order kinetic model has been used most widely to describe the biodegradation of PAEs by bacterial strains. Xu et al. [12] reported that DBP biodegradation by Pseudomonas fluorescens B-1 at very low DBP concentrations (2.5-10.0 mg/L) could be accurately described using the first-order kinetic model, and $\mathrm{Wu}$ et al. [9] reported that DBP degradation by Agrobacterium sp. fit well with first-order kinetics and that the half-life of degradation was $27.05 \mathrm{~h}$ when the DBP concentration was $500 \mathrm{mg} / \mathrm{L}$. Therefore, DBP degradation by strain $\mathrm{W}-1$ was more efficient than reported previously for other microbial strains.

Table 2. Kinetics of DBP degradation by strain W-1.

\begin{tabular}{cccc}
\hline Initial Concentration (mg/L) & Kinetic Equations & $\mathbf{R}^{2}$ & $\mathbf{t}_{\mathbf{1} / 2}(\mathbf{h})$ \\
\hline 100 & $\ln C=-0.1341 \mathrm{x}+4.6721$ & 0.9709 & 5.1 \\
200 & $\ln C=-0.0826 \mathrm{x}+5.3931$ & 0.9642 & 8.3 \\
300 & $\ln C=-0.0825 \mathrm{x}+5.8534$ & 0.9623 & 8.4 \\
400 & $\ln C=-0.0674 \mathrm{x}+6.1341$ & 0.9610 & 10.3 \\
500 & $\ln C=-0.0644 \mathrm{x}+6.4367$ & 0.9109 & 10.8 \\
\hline
\end{tabular}




\subsection{Plasmid Elimination Experiment}

It is well-known that plasmids plays an important role in the degradation of pollutants and can be useful for genetic bioaugmentation. The plasmid DNA in strain W-1 was eliminated using a series of steps. Figure 6 shows the plasmid DNA electrophoresis before and after the plasmid elimination test. In strain $\mathrm{W}-1$, one plasmid DNA with a size $<23 \mathrm{~kb}$ was identified. The results of the degradation experiment showed that W-1 could not degrade DBP and other PAEs (DMP, DEP, DOP, and DEHP) after plasmid elimination, strongly indicating that the degradation of DBP is mediated by plasmid-encoded enzymes in strain W-1. Plasmids occur naturally in several species of the genus Achromobacter. For instance, in 2000, a 70-kb plasmid, pEST4011, was shown to be responsible for the degradation of 2,4-dichlorophenoxyacetic acid by $A$. xylosoxidans subsp. denitrificans strain EST4002 [29]. In 2011, a 7-Mb chromosome and two large plasmids (98 and $248 \mathrm{~kb}$ ) were identified in the genome of A. xylosoxidans strain A8, which can use 2-chlorobenzoate and 2,5-dichlorobenzoate as the sole sources of carbon and energy [30]. Moreover, plasmids are widely known to play critical roles in the bacterial degradation of synthetic compounds. With respect to PAEs, Nomura et al. [31] reported a 7-kbp plasmid in Pseudomonas putida encoding the enzymes responsible for the initial phthalate degradation in 1992; later, a large plasmid of approximately $140 \mathrm{~kb}$ involved in the degradation of phthalates was found in Pseudomonas fuorescens [32]. In 2001, Eaton [18] reported a plasmid-encoded phthalate catabolic pathway in Arthrobacter keyseri 12B. However, there is little information available regarding PAE degradation mediated by plasmid-encoded enzymes. Thus, our results may enhance the understanding of PAE-degradation mechanisms and the functional diversity in the genus Achromobacter.

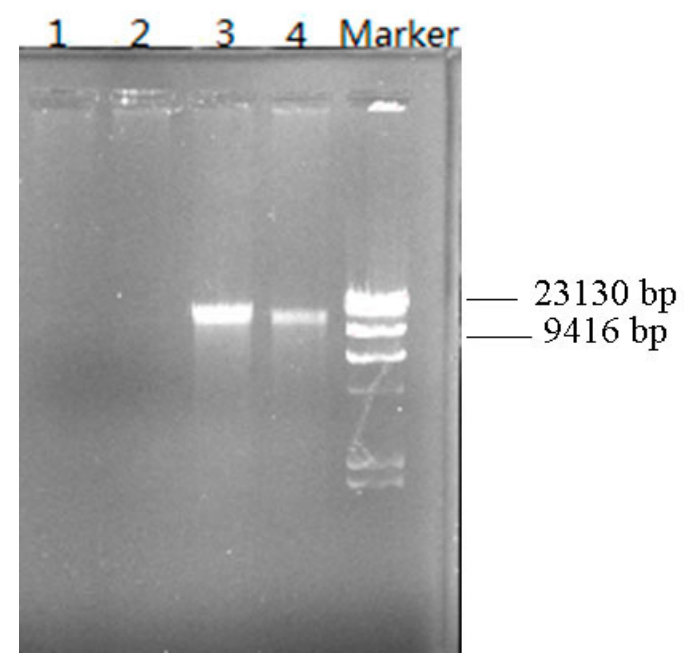

Figure 6. Plasmid DNA electrophoresis before and after the plasmid-elimination test. 1-2: Plasmid DNA after plasmid elimination; 3-4: Plasmid DNA before elimination.

\section{Conclusions}

The bacterial strain W-1, which was capable of using DBP as the sole carbon and energy source, was isolated from rural wastewater and identified as Achromobacter sp. based on its 16S rRNA gene sequences. This is the first report of using an Achromobacter sp. for DBP degradation. The optimal DBP 
degradation conditions were $\mathrm{pH} 7.0,35^{\circ} \mathrm{C}$, and agitation rate of $175 \mathrm{rpm}$. The kinetics of DBP degradation at various initial DBP concentrations (100-400 $\mathrm{mg} / \mathrm{L})$ could be described accurately using a first-order kinetic model. DBP degradation was strongly inhibited by $\mathrm{Cu}^{2+}$ and SDS and weakly inhibited by $\mathrm{Pb}^{2+}$, but the degradation was potently enhanced by Tween 20 . The degradation of DBP and other PAEs was controlled by a single plasmid present in strain $\mathrm{W}-1$. These results suggest that Achromobacter sp. W-1 can be used as a potential candidate for the efficient bioremediation of PAE-contaminated soils and water. Based on our findings, future studies should examine the mechanism of PAE degradation mediated by plasmid-encoded enzymes.

\section{Acknowledgments}

This study was supported by the Key Project of Chinese Academy of Sciences (Nos. KZZD-EW-09-3 and KZZD-EW-11-3), the National Science and Technology Major Project of China (Nos. 2012ZX07203006 and 2014ZX07204-005) and Project 135 of Chinese Academy of Sciences (No. YSW2013B06).

\section{Author Contributions}

Decai Jin and Zhihui Bai designed the experiments; Decai Jin, Xiao Kong and Yujie Li carried out the experiments and analyzed the data; Decai Jin wrote the main manuscript text; Zhihui Bai, Guoqiang Zhuang, Xuliang Zhuang and Ye Deng critically reviewed and improved the manuscript; Zhihui Bai and Ye Deng supervised the project.

\section{Conflicts of Interest}

The authors declare no conflict of interest.

\section{References}

1. Chi, J.; Gao, J. Effects of Potamogeton crispus L.-bacteria interactions on the removal of phthalate acid esters from surface water. Chemosphere 2015, 119, 59-64.

2. Lee, S.K.; Veeramachaneni, D.N. Subchronic exposure to low concentrations of di-n-butyl phthalate disrupts spermatogenesis in Xenopus. laevis frogs. Toxicol. Sci. 2005, 84, 394-407.

3. Yuan, S.Y.; Liu, C.; Liao, C.S.; Chang, B.V. Occurrence and microbial degradation of phthalate esters in Taiwan river sediments. Chemosphere 2002, 49, 1295-1299.

4. Wang, J.; Chen, G.C.; Christie, P.; Zhang, M.Y.; Luo, Y.M.; Teng, Y. Occurrence and risk assessment of phthalate esters (PAEs) in vegetables and soils of suburban plastic film greenhouses. Sci. Total. Environ. 2015, 523, 129-137.

5. Xu, N.; Chen, P.Y.; Liu, L.; Zeng, Y.Q.; Zhou, H.X.; Li, S. Effects of combined exposureto $17 \alpha$-ethynylestradiol and dibutyl phthalate on the growth and reproduction of adult male zebrafish (Danio. rerio). Ecotox. Environ. Safe. 2014, 107, 61-70.

6. Chen, X.; Xu, S.; Tan, T.; Lee, S.T.; Cheng, S.H.; Lee, F.W.F.; Xu, S.J.L.; Ho, K.C. Toxicity and estrogenic endocrine disrupting activity of phthalates and their mixtures. Int. J. Environ. Res. Public Health 2014, 11, 3156-3168. 
7. Staples, C.A.; Peterson, D.R.; Parkerton, T.F.; Adams, W.J. The environmental fate of phthalic eaters: A literature review. Chemosphere 1997, 35, 667-749.

8. Jin, D.C.; Liang, R.X.; Dai, Q.Y.; Zhang, R.Y.; Wu, X.L.; Chao, W.L. Biodegradation of di-n-butyl phthalate by Rhodococcus. sp. JDC-11 and molecular detection of 3,4-phthalate dioxygenase gene. J. Microbiol. Biotechnol. 2010, 20, 1440-1445.

9. Wu, X.L.; Wang, Y.Y.; Liang, R.X.; Dai, Q.Y.; Jin, D.C.; Chao, W.L. Biodegradation of an endocrine-disrupting chemical di-n-butyl phthalate by newly isolated Agrobacterium sp. and the biochemical pathway. Process. Biochem. 2011, 46, 1090-1094.

10. Jin, D.C.; Bai, Z.H.; Chang, D.D.; Jin, B.; Wang, P.; Wei, D.B.; Zhuang, G.Q. Biodegradation of di-n-butyl phthalate by an isolated Gordonia. sp. strain QH-11: Genetic identification and degradation kinetics. J. Hazard. Mater. 2012, 221-222, 80-85.

11. Fang, C.R.; Yao, J.; Zheng, Y.G.; Jiang, C.J.; Hu, L.F.; Wu, Y.Y.; Shen, D.S. Dibutyl phthalate degradation by Enterobacter. sp. T5 isolated from municipal solid waste in landfill bioreactor. Int. Biodeter. Biodegr. 2010, 64, 442-446.

12. Xu, X.R.; Li, H.B.; Gu, J.D. Biodegradation of an endocrine disrupting chemical di-n-butyl-phthalate ester by Pseudomonas fluorescens B-1. Int. Biodeterior. Biodegrad. 2005, 55, 9-15.

13. Chang, H.K.; Zylstra, G.J. Novel organization of the genes for phthalate degradation from Burkholderia. cepacia DB01. J. Bacteriol. 1998, 180, 6529-6537.

14. Quan, C.S.; Liu, Q.; Tian, W.J.; Fan, S.D. Biodegradation of an endocrine-disrupting chemical, di-2-ethyhexylphthalate by Bacillus subtilis No.66. Appl. Microbiol. Biotechnol. 2005, 66, 702-710.

15. Liao, C.S.; Chen, L.C.; Chen, B.S.; Lin, S.H. Bioremediation of endocrine disruptor di-n-butyl phthalate ester by Deinococcus. radiodurans and Pseudomonas stutzeri. Chemosphere 2010, 78, 342-346.

16. Vamsee-Krishna, C.; Phale, P.S. Bacterial degradation of phthalate isomers and their esters. Indian J. Microbiol. 2008, 48, 19-34.

17. Habe, H.; Miyakoshi, M.; Chung, J.; Kasuga, K.; Yoshida, T.; Nojiri, H.; Omori, T. Phthalate catabolic gene cluster is linked to the angular dioxygenase gene in Terrabacter. sp. strain DBF 63. Appl. Microbiol. Biotechnol. 2003, 6, 44-54.

18. Eaton, R.W. Plasmid-encoded phthalate catabolic pathway in Arthrobacter keyseri 12B. J. Bacteriol. 2001, 183, 3689-3703.

19. Nishioka, T.; Iwata, M.; Imaoka, T.; Mutoh, M.; Egashira, Y.; Nishiyama, T.; Shin, T.; Fujii, T. A mono-2-ethylhexyl phthalate hydrolase from a Gordonia. sp. that is able to dissimilate di-2-ethylhexyl phthalate. Appl. Environ. Microbiol. 2006, 72, 2394-2399.

20. Wu, J.; Liao, X.W.; Yu, F.B.; Wei, Z.B.; Yang, L.Y. Cloning of a dibutyl phthalate hydrolase gene from Acinetobacter. sp. strain M673 and functional analysis of its expression product in Escherichia coli. Appl. Microbiol. Biotechnol. 2013, 97, 2483-2491.

21. Zhang, X.Y.; Fan, X.; Qiu, Y.J.; Li, C.Y.; Xing, S.; Zheng, Y.T.; Xu, J.H. Newly identified thermostable esterase from Sulfobacillus. acidophilus: properties and performance in phthalate ester degradation. Appl. Environ. Microbiol. 2014, 80, 6870-6878.

22. El-Mansi, M.; Anderson, K.J.; Inche, C.A.; Knowles, L.K.; Platt, D.J. Isolation and curing of the Klebsiella. pneumoniae large indigenous plasmid using sodium dodecyl sulphate. Res. Microbiol. 2000, 151, 201-208. 
23. Wan, N.S.; Gu, J.D.; Yan, Y. Degradation of p-nitrophenol by Achromobacter. xylosoxidans Ns isolated from wetland sediment. Int. Biodeterior. Biodegrad. 2007, 58, 99-105.

24. Quan, X.C.; Shi, H.C.; Zhang, Y.M.; Wang, J.L.; Qian, Y. Biodegradation of 2,4-dichlorophenol and phenol in an airlift inner-loop bioreactor immobilized with Achromobacter. sp. Sep. Purif. Technol. 2004, 34, 97-103.

25. Xu, C.; Ding, J.H.; Qiu, J.G.; Ma, Y. Biodegradation of acetochlor by a newly isolated Achromobacter. sp. strain D-12. J. Environ. Sci. Health B 2013, 48, 960-966.

26. Ma, Z.M.; Zhu, W.J.; Long, H.Z.; Chai, L.Y.; Wang, Q.W. Chromate reduction by resting cells of Achromobacter. sp. Ch-1 under aerobic conditions. Process. Biochem. 2007, 42, 1028-1032.

27. Pradeep, S.; Sarath Josh, M.K.; Binod, P.; Sudha Devi, R.; Balachandran, S.; Anderson, R.C.; Benjamin, S. Achromobacter. denitrificans strain SP1 efficiently remediates di (2-ethylhexyl) phthalate. Ecotoxicol. Environ. Saf. 2015, 112, 114-121.

28. Jin, D.C.; Kong, X.; Cui, B.J.; Bai, Z.H.; Zhang, H.X. Biodegradation of di-n-butyl phthalate by a newly isolated halotolerant Sphingobium. sp. Int. J. Mol. Sci. 2013, 14, 24046-24054.

29. Vedler, E.; Kõiv, V.; Heinaru, A. Analysis of the 2,4-dichlorophenoxyacetic acid-degradative plasmid pEST4011 of Achromobacter. xylosoxidans subsp. denitrificans strain EST4002. Gene 2000, 255, 281-288.

30. Strnad, H.; Ridl, J.; Paces, J.; Kolar, M.; Vlcek, C.; Paces, V. Complete genome sequence of the haloaromatic acid-degrading bacterium Achromobacter. xylosoxidans A8. J. Bacteriol. 2011, 193, 791-792.

31. Nomura, Y.; Nakagawa, M.; Ogawa, N.; Harashima, S.; Oshima, Y. Genes in PHT plasmid encoding the initial degradation pathway of phthalate in Pseudomonas putida. J. Ferment. Bioeng. 1992, 74, 333-344.

32. Karpagam, S.; Lalithakumari, D. Plasmid mediated degradation of o-and p-phthalate by Pseudomonas fluorescens. W. J. Microbiol. Biotechnol. 1999, 15, 565-569.

(C) 2015 by the authors; licensee MDPI, Basel, Switzerland. This article is an open access article distributed under the terms and conditions of the Creative Commons Attribution license (http://creativecommons.org/licenses/by/4.0/). 